\title{
The Evolution of the Ngaoundéré Health Map from 1916 to 2019: A Monographic Study
}

\author{
Patrice Wam Mandeng \\ History Department \\ University of Ngaoundéré-Cameroon \\ Email: pwammandeng [AT] gmail.com
}

\begin{abstract}
From the colonial period until 2019, the city of Ngoundéré has undergone several mutational changes at many levels. Constructions, destructions and reconstructions are visible on the socially, politically, economically, culturally, religiously plan and much more. Among these upheavals, the health sector comes in at the main position, an aspect which is today privileged in the context of sustainable development. Thus, the birth of the various health infrastructures in this city denies particular attention. This article reports on the evolution of the Ngaounderé health map from 1916 to 2019. This is a diachronic study of the essentially exponential evolution of the various health structures in the city of Ngaoundéré over the long term, through the changes that this city undergoes both at administrative and health plan. In a qualitative and above all quantitative way, an inventory of the health structures of the city of Ngaoundéré in its three districts is made, while lifting a veil on the population / staff ratio dealing in this universe with divergent social realities.
\end{abstract}

Keywords---- Evolution, health map, monograph

\section{INTRODUCTION}

In general, the health situation in sub-Saharan Africa at the start of the third millennium present some flaws. Among these countries is Cameroon, whose cities have the same problem and Ngaoundéré is no exception. This could not be more alarming situation is supported by the pauperism experienced by individuals, the specter of endemics, pandemics and other natural disasters which constitute real threats to socio-economic development. Indeed, several African states, with the support of the international community, have made enormous health sacrifices to secure a workforce with a socially and economically productive life. In Cameroon, health development efforts are reflected in a set of political, strategic and structural reforms that are being implemented. "Health for all ${ }^{1 "}$ is also the political vision, even if "health everywhere ${ }^{2 "}$ remains everyone's wish. There are thus two types of alternative medicine to Ngaoundéré, namely, the so-called traditional medicine and the so-called modern, conventional medicine, also called "white medicine", which makes Ngaoundéré an in vitro laboratory for the production of therapeutic routes. Everything happens between the public sector, the private sector and non-conventional medicine, also called traditional medicine. Indeed, the sanitary system of Ngaoundéré knows obstacles of several orders which prevent its good functioning. This observation is visible all the more since during the last update of the health map of Cameroon by the Ministry of Public Health, it appears that in 2016, out of the 3,343 existing health facilities, only 1,055 have a decree governing their operation and 2288 operate illegally. To bring a downside to this exponentially growing phenomenon, several efforts are being made by the Government for the smooth running of this sector of activity, in order to promote conventional medicine. This article is the place to take stock of all the health facilities in the city of Ngaoundéré, in order to bring out an updated health map from 1916 when the very first health facility was established in Ngaoundéré, passing through 2016, date of updating the health map of Cameroon, until 2019, date on which our work stops and the establishment of our health map.

\section{CONCEPTS OPERATIONALIZATION}

To better and more clearly define the contours of this subject, it is necessary not only to grasp the concepts whose understanding requires a clear definition, but also to render them operational in our context. So, a few concepts caught our attention. These include the terms

Evolution, Health map and Monograph

The term evolution designates any type of a set of gradual changes accumulated over time, affecting an object (planet, relief, ocean, manufactured object, etc.), a living being (growth and aging for example), a population ( evolution of species),

\footnotetext{
${ }^{1}$ D. Kondji Kondji, 2005, « Politique et système de santé »; Evolution historique au Cameroun : de la conceptualisation à l'opérationnalisation..

${ }^{2}$ Archive of the ministry of public health in Cameroon.
} 
a system (evolution example), a population ( evolution of species), a system (evolution of the climate, historical evolutions, economic evolutions, social evolutions, etc.) or even though (evolution of ideas) and behavior (evolution of mores) ${ }^{3}$.

The health map is defined as all the health areas in the district. Chauvancy Marie Claire in her March 2009 report defines the health map as a regional organizational scheme ${ }^{4}$. According to Wikipedia, the health map is a management and planning tool that gives a vision of the care needs of the entire population ${ }^{5}$. In the context of this article, we mean by health map, all public and private health facilities available in a region. The Ngaoundéré health map should be understood in this context.

A Monograph is originally a non-periodic book or treaty, that is to say complete in one volume or intended to be completed in a limited number of volumes. It can also be defined as an in-depth study limited to a particular social fact and based on direct observation which, bringing into contact with concrete facts, participates in lived experience. Now the term monograph is mostly used when talking about a "comprehensive and broad study of a specific and limited subject, or of a character ${ }^{6}$."

\section{THEORITICAL APPROACH}

In order to better understand this subject, a very specific theoretical framework has been built. It's Structuralism. Developed by sociologists, anthropologists, psychologists, economists, historians, theoreticians of literature, linguists and also philosophers, structuralism according to Claude Levi-Strauss ${ }^{7}$ is the set of kinship systems making it possible to think that man considered as a being thinking, social, communicating with fellow humans will be able to be an object of science. Thus, the structure has a logical but implicit organization, an objective foundation below consciousness and thought therefore, structuralism aims to highlight these unconscious structures. For structuralists, social processes arise from fundamental structures which most often remain unconscious. Social organization thus generates certain practices and beliefs specific to the individuals who depend on them. This theory seeks to explain a phenomenon from the place it occupies in a system according to the laws of association and dissociation ${ }^{8}$. Structuralism has had an impact on the historian in general and on man in particular in that it has developed in him the spirit of building infrastructure for good development. The structures here are, the construction of the buildings, in particular, those with sanitary vocation and which consequently are at the base of this study. The health map of Ngaoundéré is the set of health structures, public and private, which exist on this territory

\section{METHODOLOGICAL APPROACH}

The writing of this article was subject to a well-defined methodology beforehand. This was done in several stages which should be presented here.

The very first phase was that of reading. Thus, the libraries and archives of the regional delegation of Adamawa were visited with regard to written sources. As for electronic sources, several documents were consulted online, while the images and illustrations formed an iconographic database. A second phase is that of the collection of oral data. It was done through a field trip during which observation, interviews and distribution of a questionnaire were scheduled. The weapons used here are: the Android phone which was used not only for taking the photos but also for the recordings, a notepad, a ballpoint pen and a GPS to locate with precision the points spotted. Third, a content analysis was made, followed by data processing which led to the results, the construction of the Ngaoundéré health map, which will be presented in the following lines

\section{4-THE EVOLUTION OF THE HEALTH MAP IN NGAOUNDERE (1916-2018)}

During the French administration, Cameroon included seventeen (17) command units divided into administrative subdivisions $^{9}$, including Ngaoundéré, which is the subject of this study. Thus, between 1916 and 1955 the northern part of Cameroon faced four (04) changes due to the establishment of several administrative units. Indeed, there are now two health districts in urban Ngaoundéré. These have four health areas namely Bamynga, Boundjéré, Ndelbe, Sabongari with a population of 244,861. Ngaoundéré Rural has fourteen health areas which are Beka-hosséré, Belel, Dang, Dibi, Likok, Martap, Mbang-Mboum, Mbé, Ngan'ha, Nyambaka, Sassa-Mbersi, Tourningal, Wack, Wassandé For a population of 205,428 inhabitants ${ }^{10}$.

\footnotetext{
${ }^{3}$ https://fr.m. wikipedia.org, consulted on the $14^{\text {th }}$ of May 2019 at 10:56pm.

${ }^{4}$ C. M. Chauvancy dans son rapport de Mars 2009 : les reformes hospitalières et leur impact sur l'encadrement infirmier.

5 https://fr.m.wikipedia.org, consulted on the $14^{\text {th }}$ of May 2019 at 10:56pm.

${ }^{6}$ National Center of textual and lexical resources on the 17/03/2011, in https://fr.m.wikipedia.org, consulted on the $14^{\text {th }}$ of May 2019 at 10:56pm.

${ }^{7}$ Levi-Strauss is a structural anthropologist and one of the founding fathers of the theory of structuralism.

${ }^{8} \mathrm{http}:$ //www.ac-bordeaux.fr/Etablissement/JMonnet/ses/coursocio/socio.htm, consulted on the $27^{\text {th }}$ of March 2017.

${ }^{9}$ Djuitchou. Kemdem, 2012, « la promotion de la santé maternelle et infantile à Ngaoundéré 1960-2012 », mémoire de master recherche en histoire, université de Ngaoundéré P.28.

${ }^{10}$ Archive of the regional delegation of public health of Adamawa.
} 
Two major events have marked the Ngaoundéré health system. The first is its administrative independence and the second is the establishment of a health district.

The health map of Ngaoundéré has known a great evolution since 1916 until our days, because we passed from two health centers namely the German medical station and the Norwegian Protestant mission to several health centers across the city of Ngaoundéré this in order to improve health. In 1916 the city of Ngaoundéré had a health hut within it. However, modern medicine has relatively evolved in health behaviors from the actions of certain agents, including the French administration, the Norwegian mission and the Cameroonian administration in Cameroon. However, from 1916 to 2016, the health map of Ngaoundéré underwent a change both in terms of health methods and in health policy itself. This health policy has had several impacts both internationally and nationally. Thus all the decisions which were taken on the national level had repercussions on Ngaoundéré ${ }^{11}$. However, the city of Ngaoundéré already had within it its first health structure set up by the German colonial administration represented by Captain Kauffmann ${ }^{12}$. The building is located on the site of the Ngaoundéré regional hospital. The photo below shows the first structure.

Photo 1: Colonial health hut

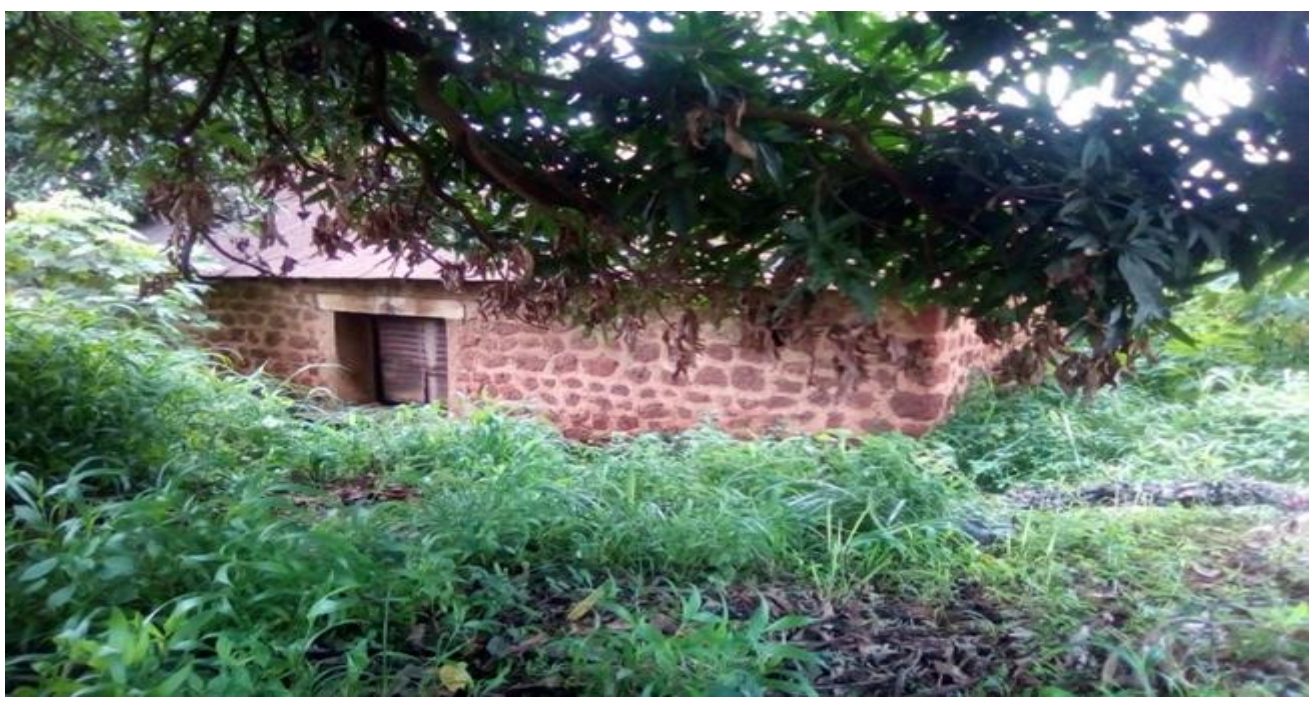

Source: Photo taken by Touah Bikélé Gildas, Ngaoundéré on June 1, 2017.

This building is the first building constructed by the Germans who then occupied the same premises. Several oral sources informed us that the French administration on its arrival in Ngaoundéré had the said building was already in place. As soon as they arrived, the French occupied this building which served them as a boarding room for the patients.

Photos 2 and 3: A prisoner consultation room.

\footnotetext{
${ }^{11}$ Interview with Emmanuel Betsi of the "cheque sante"project of Adamawa on the 30 ${ }^{\text {th }}$ of May 2016.

${ }^{12}$ P. Fadibo, Problématique d'accès aux soins de santé dans le district sanitaire de Ngaoundéré (1916-2010) P.12.
} 


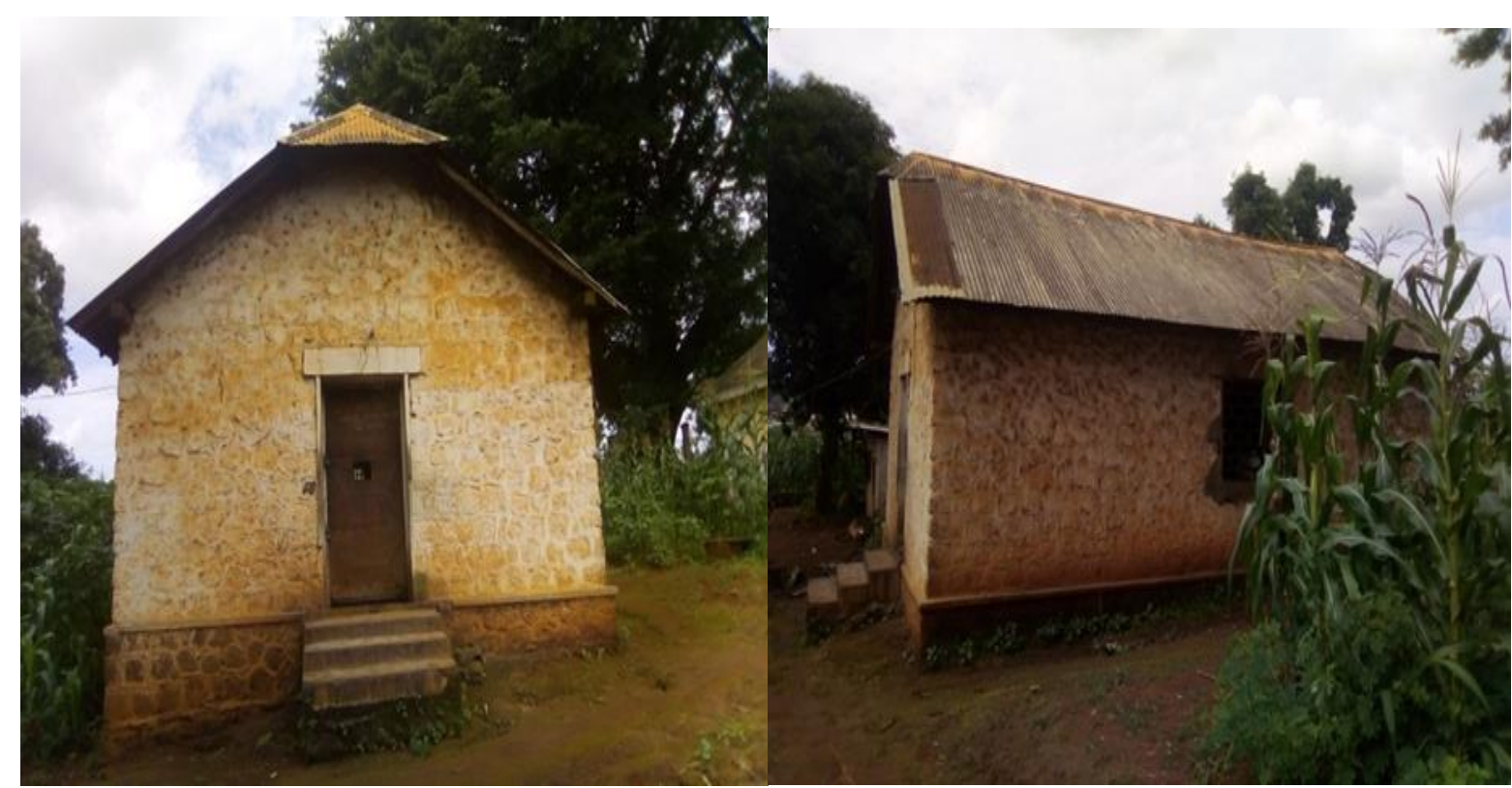

Source: Photo taken by Touah Bikélé Gildas, Ngaoundéré on June 1, 2017.

This building was also the German work. Later, however, served the French administration as a consultation room. Currently this building is reserved for prisoners who receive intensive care inside this room ${ }^{13}$.

Photo 4 and 5: A consultation room built in 1983

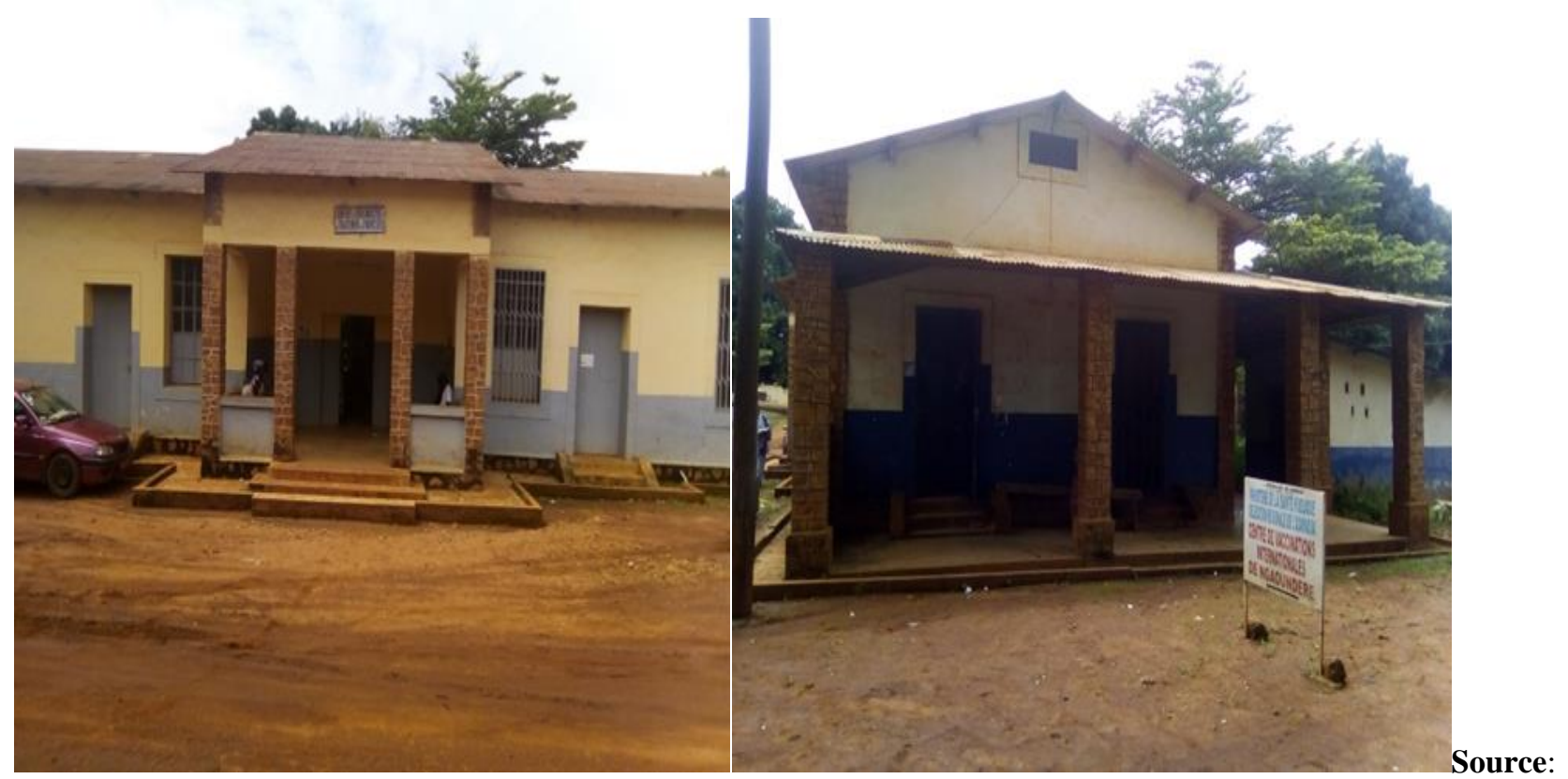

Photo taken by Touah bikele gildas,Ngaoundere on june $1^{\text {st }} 2017$.

This building also served as a consultation room for the German administration in their health mission in Ngaoundéré. Indeed, this building until today is operational it is the current building where are taken care of the patients of tuberculosis note all the same that for this building, it was set up in 1983 for the consultation of the patients ${ }^{14}$. However, after the German work of 1916, the Norwegian Protestant mission arrived in Ngaoundéré in 1925 . In order to provide care to the local population of the city, they were given a health facility.

In 1980, with the contribution of Norad, expansion work began. By April 1982, this site was completed and new buildings put up were estimated at a sum of 200,000,000 CFA francs. There was the opportunity to have a maternity, maternal and

${ }^{13}$ Interview with Ismaela Hamadama, security guard of the regional hospital of Ngaoundere on the $28^{\text {th }}$ of July 2017.

${ }^{14}$ Interview with an anonymous person on the actual site of Ngaoundere general hospital on the $28^{\text {th }}$ of July 2017. 
child protection (PMI), a clinic with boarding school, an ophthalmological clinic and six residential houses. After this health hut built by the German administration in 1916, the Ngaoundéré health card has undergone a major evolution in health infrastructure as shown in the table below.

Table 1: Distribution of health facilities in Ngoundéré $1^{\text {st }}$

\begin{tabular}{|c|c|c|c|c|c|}
\hline DISTRICT & $\begin{array}{l}\text { HEALTH } \\
\text { AREA }\end{array}$ & NAME OF STRCUCTRE & CATEGORY & STATUS & $\begin{array}{l}\text { POPULA } \\
\text { TION }\end{array}$ \\
\hline \multirow{32}{*}{$\begin{array}{c}\text { Ngaoundéré } \\
\mathbf{1}^{\text {st }}\end{array}$} & \multirow{4}{*}{ BAMYANGA } & CSIPC Bamyanga Marza & CSI & $\begin{array}{l}\text { Private } \\
\text { denominational }\end{array}$ & \multirow{4}{*}{49921} \\
\hline & & CSPC YVES PLUMEY & CSI & $\begin{array}{l}\text { Private } \\
\text { denominational }\end{array}$ & \\
\hline & & CS Bamyanga Hamadjangui & CSI & Public & \\
\hline & & Cabinet de Soins la Guérison & $\mathrm{CS}$ & $\begin{array}{l}\text { Private } \\
\text { denominational }\end{array}$ & \\
\hline & \multirow{25}{*}{ BOUMDJERE } & DRSP AD & $\begin{array}{l}\text { S. } \\
\text { Coordination }\end{array}$ & Public & \multirow{25}{*}{67293} \\
\hline & & SSD & $\begin{array}{l}\text { S. } \\
\text { Coordination }\end{array}$ & Public & \\
\hline & & Hôpital Régional & Hospital & Public & \\
\hline & & Cabinet Médical Militaire & Hospital & Public & \\
\hline & & Clinique La Patience & Hospital & Private for-profit & \\
\hline & & Centre Médical de la Police & $\mathrm{CS}$ & Public & \\
\hline & & Centre Médical de la Prison & $\mathrm{CS}$ & Public & \\
\hline & & CSI Boumdjéré & CSI & Public & \\
\hline & & CSI Islamique Privé & CSI & $\begin{array}{l}\text { Private } \\
\text { denominational }\end{array}$ & \\
\hline & & CSIC Louis M.B. Nord-Cifan & CSI & $\begin{array}{l}\text { Private } \\
\text { denominational }\end{array}$ & \\
\hline & & Cabinet de soins Boumdjéré & $\mathrm{CS}$ & Private for-profit & \\
\hline & & Cabinet de soins Bien Etre & $\mathrm{CS}$ & Private for-profit & \\
\hline & & Cabinet de soins la Référence & $\mathrm{CS}$ & Private for-profit & \\
\hline & & CSPI Malam Aoudou Tapparé & $\mathrm{CS}$ & Private for-profit & \\
\hline & & Cabinet de soins LAKENPA & $\mathrm{CS}$ & Private for-profit & \\
\hline & & GIFT Optical & $\mathrm{CS}$ & Private for-profit & \\
\hline & & ECHO-MED & $\mathrm{CS}$ & Private for-profit & \\
\hline & & Pharmacie de l'Entente & Officine & Private for-profit & \\
\hline & & Pharmacie Carrefour Aoudi & Officine & Private for-profit & \\
\hline & & Pharmacie OXYGENE & Officine & Private for-profit & \\
\hline & & Pharmacie la VINA & Officine & Private for-profit & \\
\hline & & Pharmacie de l'Espérance & Officine & Private for-profit & \\
\hline & & Pharmacie du grand marché & Officine & Private for-profit & \\
\hline & & Lunetterie Optique Top Color & Officine & Private for-profit & \\
\hline & & Laboratoire analyse M. Damari & Laboratory & Private for-profit & \\
\hline & \multirow{3}{*}{ NDELBE } & CSI NDELBE & CSI & $\begin{array}{l}\text { Private } \\
\text { denominational }\end{array}$ & \multirow[t]{2}{*}{55954} \\
\hline & & Cabinet de soins de Burkina & $\mathrm{CS}$ & Private for-profit & \\
\hline & & Hôpital Protestant de Ngaoundéré & Hospital & $\begin{array}{l}\text { Private } \\
\text { denominational }\end{array}$ & \\
\hline
\end{tabular}

This table present the distribution of the different health facilities in the district of Ngaoundere $1^{\text {st }}$, which gives the summary below. 
Table 2: Summary of the distribution of health facilities by category and by legal classification in the district of Ngaoundéré 1er.

\begin{tabular}{|l|c|c|c|}
\hline \multirow{2}{*}{ TYPE OF TRAINING } & \multicolumn{2}{|c|}{ LEGAL CLASSIFICATION } & \multirow{2}{*}{ TOTAL } \\
\cline { 2 - 3 } & PUBLICS & PRIVATES & \\
\hline CS & 9 & 3 & $\mathbf{1 1}$ \\
\hline CSI & 2 & 5 & $\mathbf{7}$ \\
\hline C. COORDINATION & 2 & 0 & $\mathbf{2}$ \\
\hline HÔSPITAL & 2 & 2 & $\mathbf{4}$ \\
\hline OFFICINE & 0 & 8 & $\mathbf{8}$ \\
\hline LABORATORY & 0 & 1 & $\mathbf{1}$ \\
\hline TOTAL & $\mathbf{1 5}$ & $\mathbf{1 9}$ & $\mathbf{3 3}$ \\
\hline
\end{tabular}

Source: Patrice Wam Mandeng, result of the field investigation.

This table shows the distribution of health facilities in the Ngaoundére 1er district. As a result, this Arrondissement, which brings together approximately 173,168 inhabitants, has 33 health facilities, many of which include CS Health Centers, CSI Integrated Health Centers, CC Coordination Centers, Hospitals, pharmacies, pharmacies and a laboratory. It should be noted here that among these health facilities, some are public, others private and even private denominational as presented in the distribution table above. Finally, we note that private and faith-based for-profit health centers are in high number, while public institutions are rare and in fewer numbers. This distribution is easily seen thanks to the grouped histogram below.

\section{Grouped histogram of the distribution of health facilities in the arrondissement of Ngaoundéré 1st}

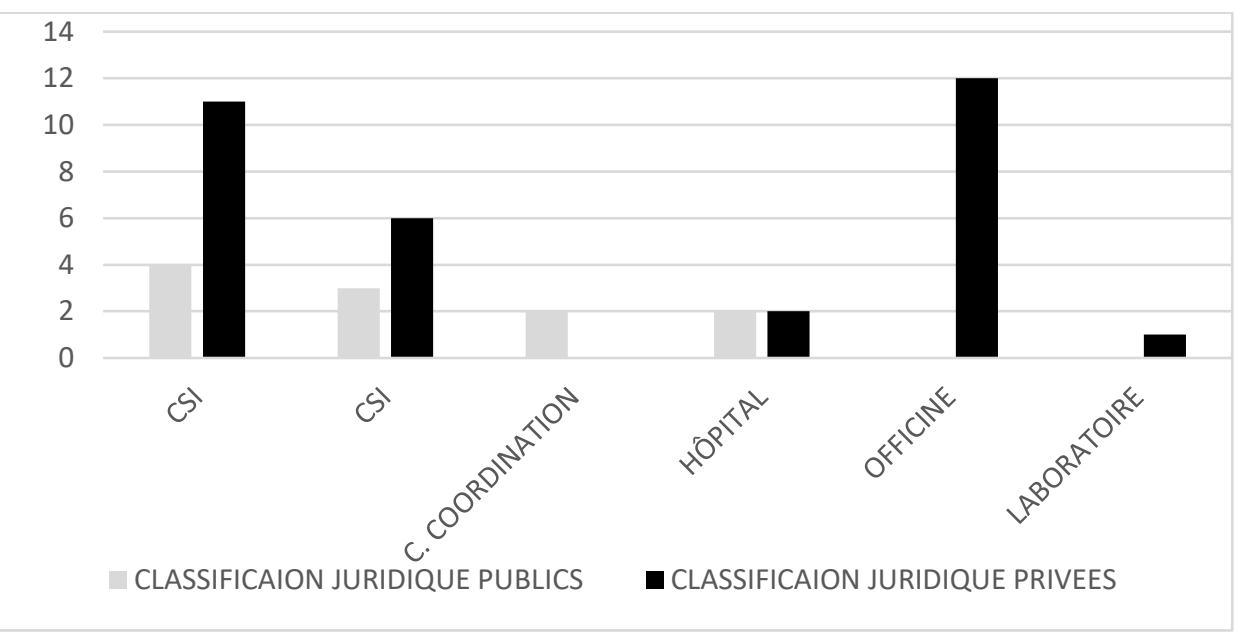

Source : Patrice Wam Mandeng, result of the field investigation. 


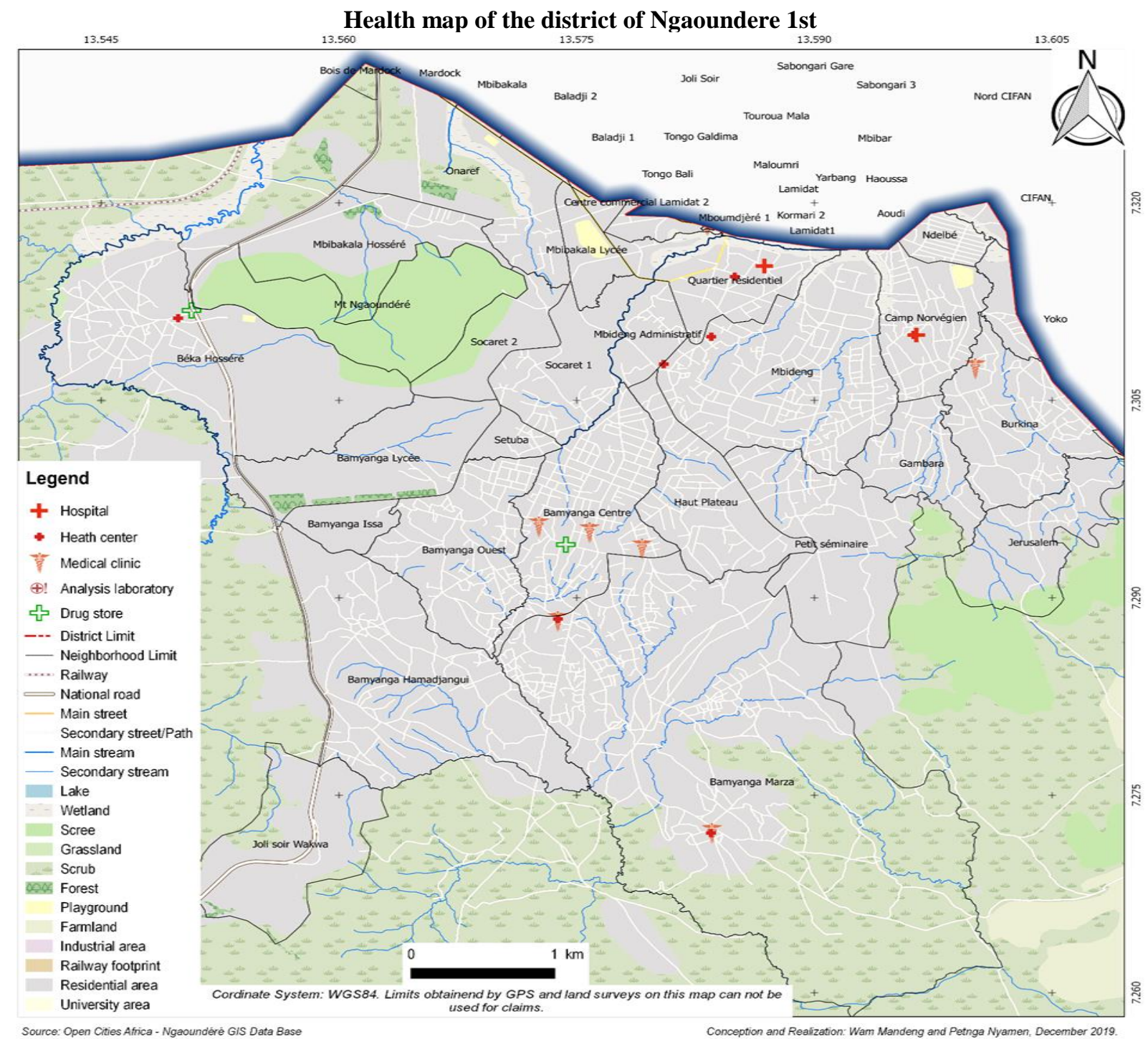

Table 3: Distribution of health structures in Ngaoundere $2^{\text {nd }}$

\begin{tabular}{|c|c|c|c|c|}
\hline DISTRICT & HEALTH AREA & STRUCTURE NAME & CATEGORY & STATUS \\
\hline \multirow{9}{*}{ Ngaoundéré $2^{\text {nd }}$} & \multirow{9}{*}{ SABONGARI } & CSI SABONGARI & CSI & Public \\
\hline & & CSIPC Gada Mabanga & CSI & $\begin{array}{l}\text { Private } \\
\text { denominational }\end{array}$ \\
\hline & & Centre Médical Camrail & CS & Parapublic \\
\hline & & Clinique Islamique $\mathrm{AD}$ & Hospital & Private for-profit \\
\hline & & Cabinet de soins La Relève & CS & Private for-profit \\
\hline & & CS SALAM & CS & Private for-profit \\
\hline & & Pharmacie ADAMA & Officine & Private for-profit \\
\hline & & Pharmacie le SARE SARL & Officine & Private for-profit \\
\hline & & Pharmacie de la Gare & Officine & Private for profit \\
\hline
\end{tabular}


Table 4: Summary of the distribution of health structures by juristic category and classification in the district of Ngaoundere $2^{\text {nd }}$

\begin{tabular}{|l|c|c|c|}
\hline \multirow{2}{*}{ TYPE OF TRAINING } & \multicolumn{2}{c|}{ LEGAL CLASSIFICATION } & \multirow{2}{*}{ TOTAL } \\
\cline { 2 - 3 } & PUBLICS & PRIVATE & \\
\hline CS & 1 & 2 & $\mathbf{3}$ \\
\hline CSI & 1 & 2 & $\mathbf{3}$ \\
\hline C. COORDINATION & 0 & 0 & $\mathbf{0}$ \\
\hline HOSPITAL & 0 & 1 & $\mathbf{1}$ \\
\hline OFFICINE & 0 & 3 & $\mathbf{3}$ \\
\hline LABORATORY & 0 & 0 & $\mathbf{0}$ \\
\hline TOTAL & $\mathbf{2}$ & $\mathbf{8}$ & $\mathbf{1 0}$ \\
\hline
\end{tabular}

Source: Patrice Wam Mandeng, result of the field investigation.

From this table, its shows that the district of Ngaoundere $2^{\text {nd }}$ count 10 health facilities whose classification is not different of that saw in Ngaoundere $1^{\text {st }}$. This district count around 66801 inhabitant who regularly visit these diversify health facilities, private, public and even para public whose representation is more perceive in this histogram.

\section{Group histogram of the distribution of health facilities in the district of Ngaoundere $2^{\text {nd }}$}

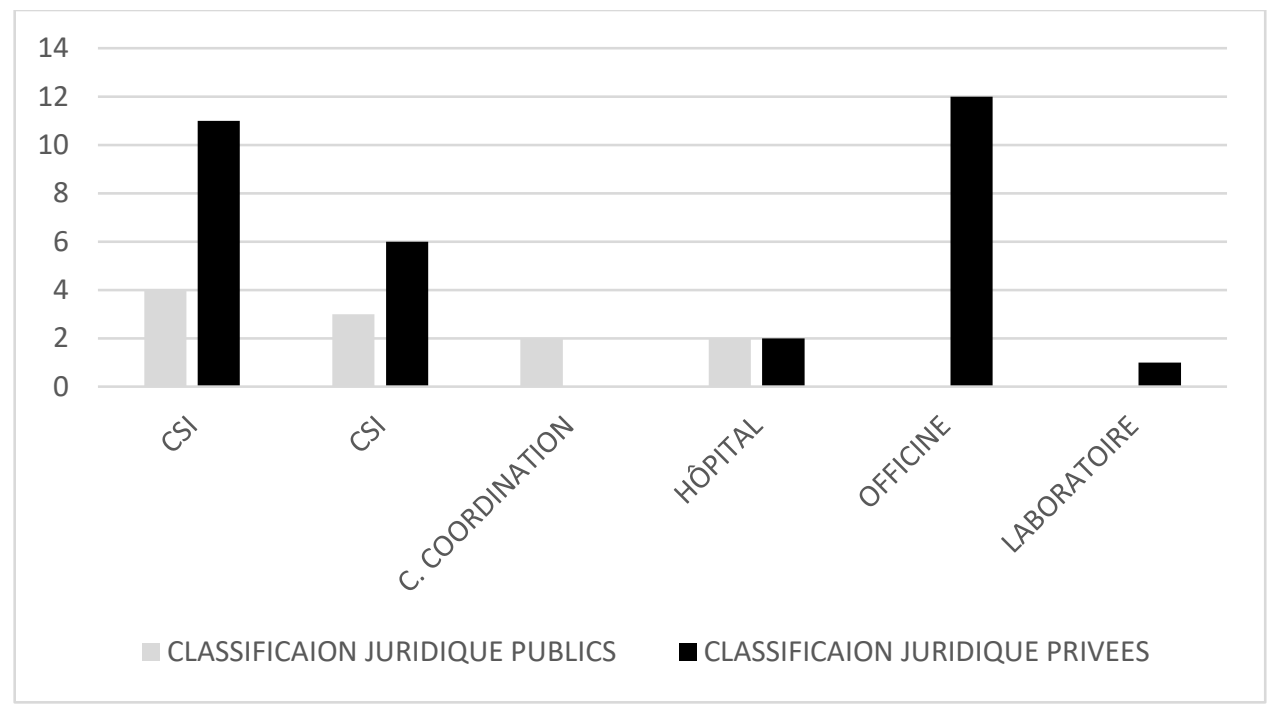

Source: Patrice Wam Mandeng, result of the field investigation 


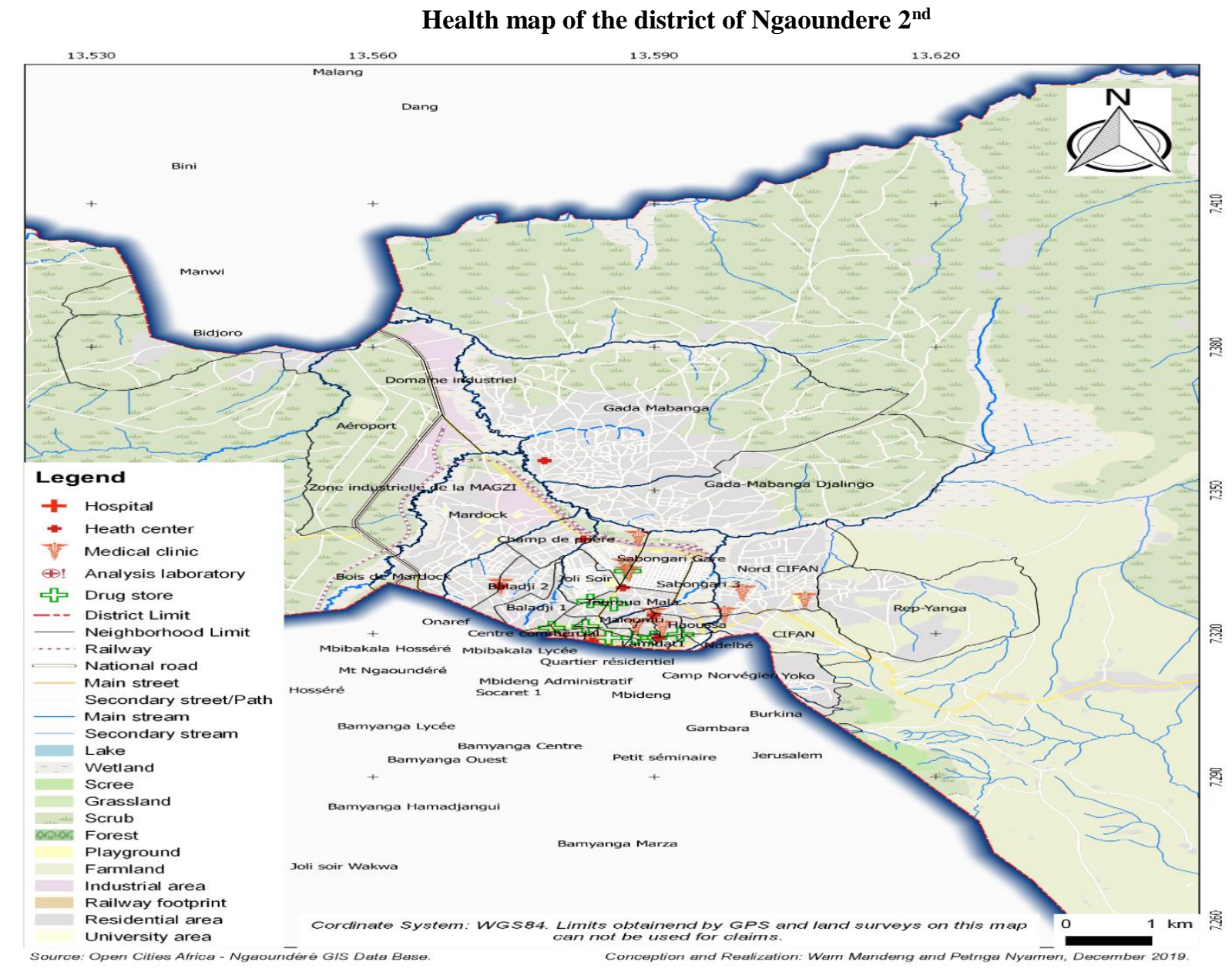

Table 5: Distribution on health structures in Ngaoundere 3rd

\begin{tabular}{|l|l|l|l|l|}
\hline district & $\begin{array}{l}\text { Health } \\
\text { areas }\end{array}$ & Structure name & Category & Status \\
\hline \multirow{2}{*}{ Ngaoundéré 3rd } & \multirow{2}{*}{ Dang } & CMA de Dang & CMA & Public \\
\cline { 3 - 5 } & $\begin{array}{l}\text { Hôpital protestant de } \\
\text { Dang }\end{array}$ & Hôpital de District & $\begin{array}{l}\text { Private } \\
\text { denominational }\end{array}$ \\
\cline { 3 - 5 } & $\begin{array}{l}\text { Centre Medico Sanitaire } \\
\text { universitaire }\end{array}$ & CMS & Pulblic \\
\hline
\end{tabular}

Source: Patrice Wam Mandeng, result of the field investigation 
Table 6: Summary of the distribution of health structures by category and by juridical classification in the district of Ngaoundere 3rd

\begin{tabular}{|l|c|c|c|}
\hline \multirow{2}{*}{\multicolumn{1}{|c|}{ TYPE OF TRAINING }} & \multicolumn{2}{c|}{ LEGAL CLASSIFICATION } & \multirow{2}{*}{ TOTAL } \\
\cline { 2 - 3 } & PUBLICS & PRIVATE & \\
\hline CMA & 1 & 1 & $\mathbf{2}$ \\
\hline CSI & 0 & 0 & $\mathbf{0}$ \\
\hline C. COORDINATION & 0 & 0 & $\mathbf{0}$ \\
\hline HOSPITAL & 0 & 1 & $\mathbf{1}$ \\
\hline OFFICINE & 0 & 1 & $\mathbf{1}$ \\
\hline LABORATORY & 0 & 0 & $\mathbf{0}$ \\
\hline TOTAL & $\mathbf{1}$ & $\mathbf{3}$ & $\mathbf{4}$ \\
\hline
\end{tabular}

Source: Patrice Wam Mandeng, result of the field investigation

In this table, we can easily read that the health structure conferred to Ngoaundere $3^{\text {rd }}$ are limited despite the fact that certain informant sees that this number turn to expand progressively in term of the essentially exponential expansion of the population whose majority is constituted of student since 1993, date of the transformation of the university center of Ngaoundere to the University of Ngaoundere four health facilities (02 health district center,01 hospital,01 pharmacy) still 2019, for a population of around 300000 inhabitant. This distribution can be better illustrated by the histogram below.

\section{Group histogram of the distribution of health facilities in Ngaoundere 3rd district}

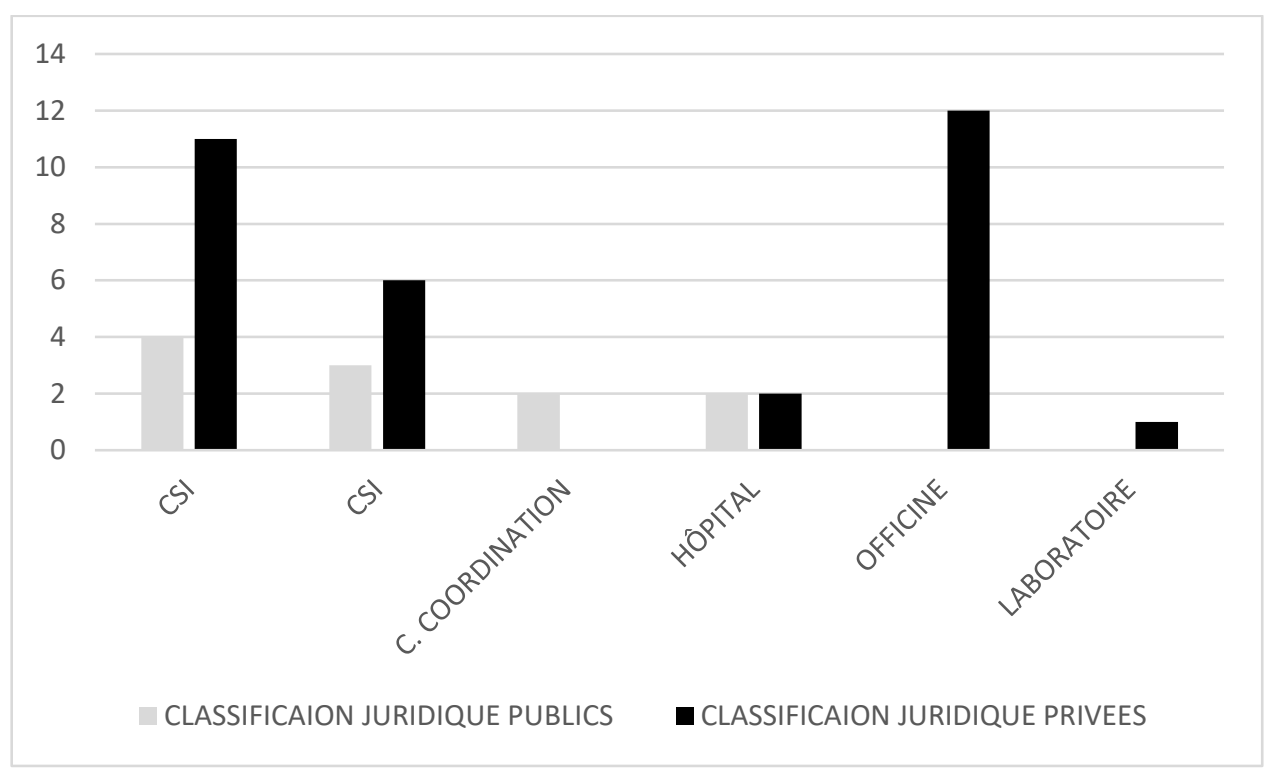

Source: Patrice Wam Mandeng, result of the field investigation 


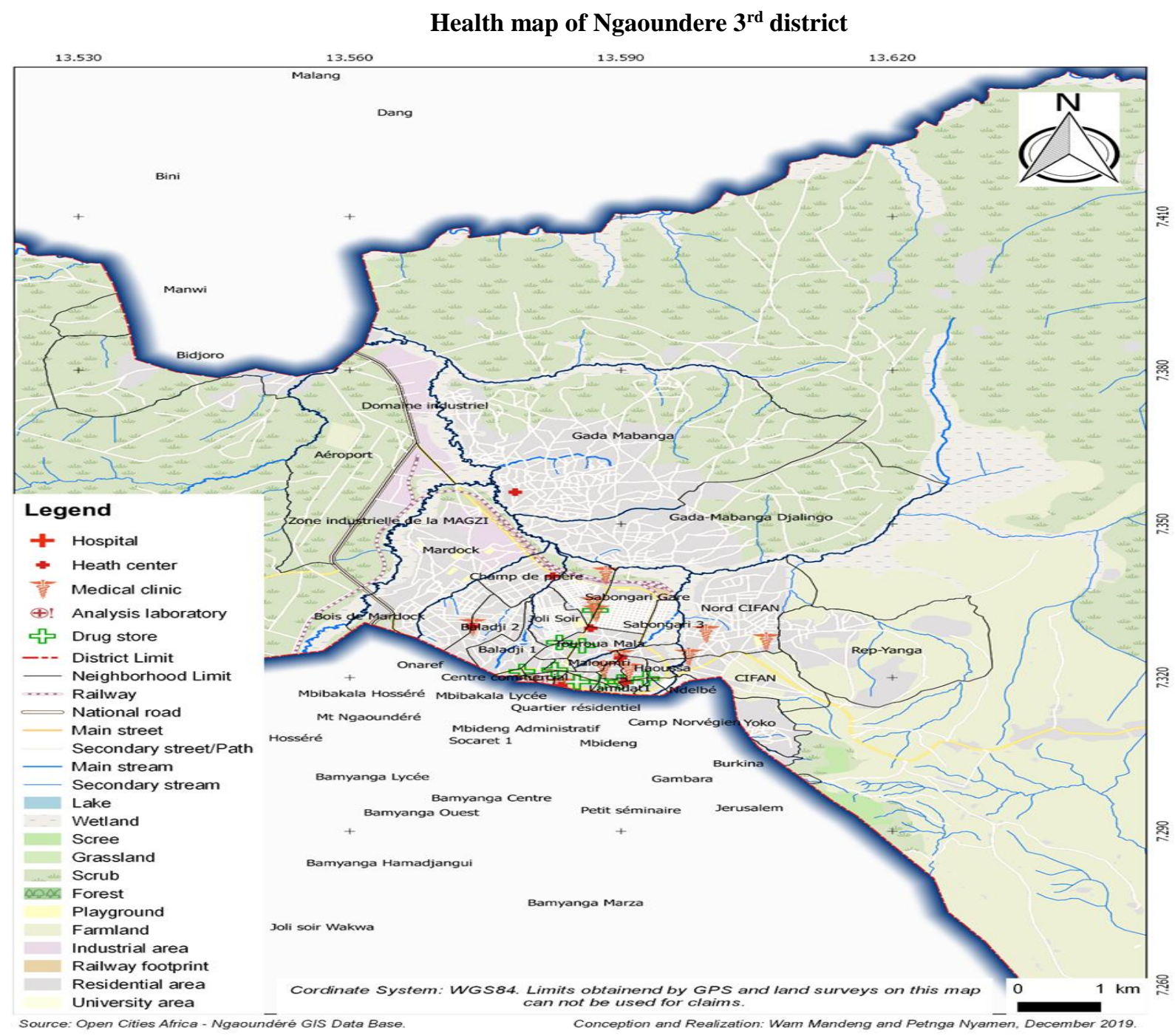

Table 7: Summary of the distribution of health facitlities in Ngaoundere from 1916 to 2019

\begin{tabular}{|l|c|c|c|}
\hline \multirow{2}{*}{ TYPE OF TRAINING } & \multicolumn{2}{|c|}{ LEGAL CLASSIFICATION } & \multirow{2}{*}{ TOTAL } \\
\cline { 2 - 3 } & PUBLICS & PRIVATE & \\
\hline CMA & 1 & 1 & $\mathbf{2}$ \\
\hline CSI & 4 & 11 & $\mathbf{1 5}$ \\
\hline CS & 3 & 6 & $\mathbf{9}$ \\
\hline C. COORDINATION & 2 & 0 & $\mathbf{2}$ \\
\hline HOSPITAL & 2 & 2 & $\mathbf{4}$ \\
\hline OFFICINE & 0 & 12 & $\mathbf{1 2}$ \\
\hline LABORATORY & 0 & 1 & $\mathbf{1}$ \\
\hline TOTAL & $\mathbf{1 2}$ & $\mathbf{3 3}$ & $\mathbf{4 5}$ \\
\hline
\end{tabular}

Source: Patrice Wam Mandeng, result of the field investigation.

This table summarizes the distribution of all the health facilities in the three Arrondissements of the city of Ngaoundéré. Here, it is clearly established that the various health facilities encountered in Ngaoundéré are the CMA, the CSI, the CS, the CC, the Hospitals, the Pharmacies and the Laboratories. Of the 45 health facilities registered throughout the city, from 1916 to 2019, 12 are state-owned, while 33 are either private for profit, or denominational private still for profit. It should also be noted that the population of the city of Ngaoundéré is essentially growing and today reaches approximately 205,428 
inhabitants. It is all the same fashionable to mention that this city has only 4 Hospitals of which 02 are public and 02 others private. Of all the registered structures, those belonging to the private sector are higher and also, they are for-profit, which until today poses a real problem of access to healthcare in Ngaoundéré. The representativeness of the different sectors (private and public) is clearly observable in the circular diagram below.

\section{Circular diagram summarizing the distribution of health structures in the 3 districts of Ngaoundere.}

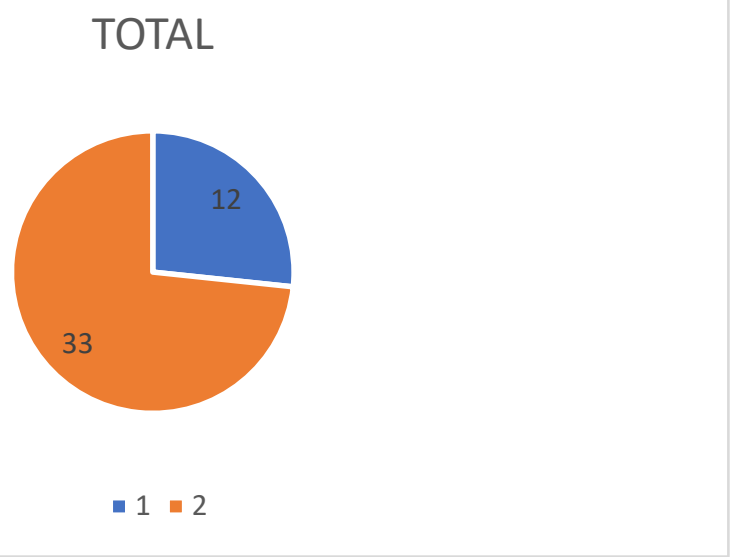

Source: Patrice Wam Mandeng, result of the field investigation.

Health map of the city of Ngaoundere.

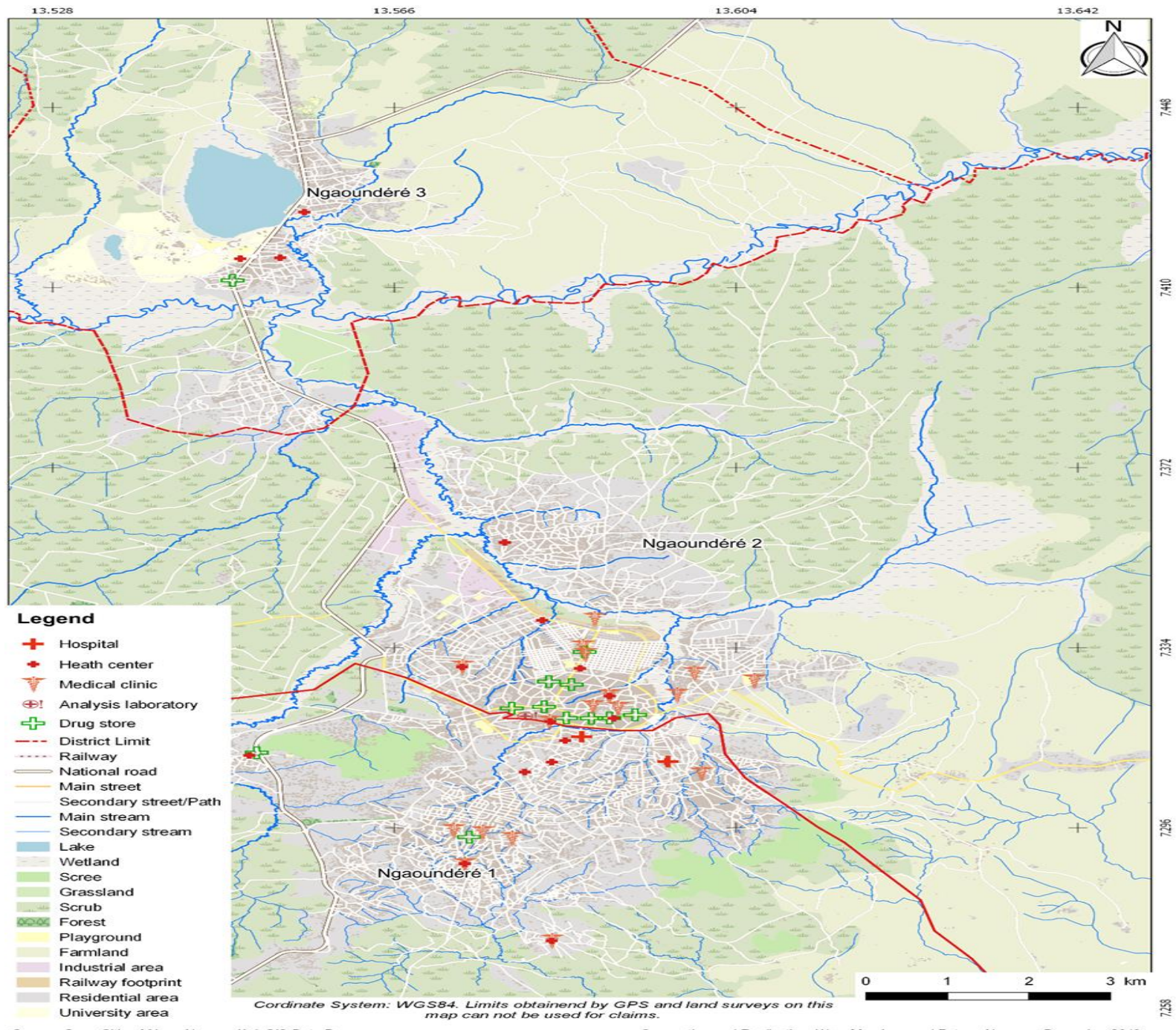


Through this map, it appears that the health landscape of the city of Ngaoundéré is dotted with several health centers which evolve according to the demographic growth of the populations of the region. Indeed, health centers are the places where medical services are provided. These are the places where preventive curative care and health education are provided. Thus, the gathering of these health centers makes them the promotion of modern medicine because it comes to relieve the sick and the whole community insofar as these are intended for them ${ }^{15}$. Therefore, the decree $\mathrm{N}^{\circ} 68-419$ of October 15 fixing the organization in health and hospital training of Cameroon in its article 2 paragraph 1 and 2, gives the intervention levels of public health centers ${ }^{16}$. So the question that arises is whether these different health facilities are able to provide care for patients in the city of Ngaoundéré. This is to provide some answers, the distribution table below is developed.

Table 8: Training ratios and health personnel in $2007^{17}$.

\begin{tabular}{|l|l|}
\hline Ngaoundéré Urban & Ngaoundéré Rural \\
\hline 1 Doctor for 16500 inhabitants & 1Doctor for 17000 inhabitants \\
\hline 1 health worker for 1900 inhabitants & 1 health worker for 1500 inhabitants \\
\hline 1 health area for all the $860 \mathrm{~km} 2$ & 1 health area for all the $400 \mathrm{~km} 2$ \\
\hline 1 health area for 41500 habitants & 1 health area for 7200 inhabitants \\
\hline 1 health unit for 11000 inhabitants & 1 health unit for 4400 inhabitants \\
\hline
\end{tabular}

Sources: Ngaoundéré district health service (SSD) 2007 annual report ${ }^{18}$.

We note a clear improvement in the health map of Ngaoundéré compared to the year 2007, Indeed Pierre Fadibo Cameroonian Historian rightly pointed out: If the health map and the ratio in 2007 do not quickly suggest a disparity in the capacity of health areas, it should at least be noted that populations are much more concentrated in urban health areas. This is justified by the fact that the city still concentrates most of the social infrastructure, and therefore becomes a pole of attraction even for people of rural origin, as F. Fournet and G Salem recognize when they write: "The cities are favored over the countryside, they absorb most of the country's health resources" ${ }^{19}$. In the district of Ngaoundéré, this situation is verified from the majority of health facilities that the city alone concentrates that is 35 out of 47 . And, in this concentration of populations in urban areas, it must be understood that there is mobilization of personnel qualified health at the expense of rural areas. This already poses a problem of the quality of services in the health structures responsible for supervising the large peasant mass, whose problems are not negligible areas. This already poses a problem of the quality of services in the health structures responsible for supervising the large peasant mass, whose problems are not negligible. The situation in the Ngaoundéré health district can be compared, to a certain extent, to what Véronique Lucas and François Tonnellier describe in France in the Paris region. These actors reach the conclusion that "the general practitioners are much more numerous in the center of the cities (in proportion to the population) whereas they represent the access of first aid which should be the most egalitarian" 20 .

\section{CONCLUSION}

After operationalizing the concepts, structuralism, which is a theory developed by sociologists, anthropologists, psychologists, economists, historians, theoreticians of literature and even philosophers, allowed us to choose a well-defined methodological approach. This facilitated a good collection and analysis of data, the interpretation of which enabled the following results to be obtained.

- From 1916 to 2019, the health map of Ngaoundéré experienced essentially exponential development;

- From 1916 until 2019, the city of Ngaoundéré has had 45 various health facilities, 12 of which are public and 33 in the private sector;

${ }^{15}$ Djuitchou Kemdem, 2012, « la promotion de la santé maternelle et infantile à Ngaoundéré (1960-2012) », mémoire en Histoire Université de Ngaoundéré p. 84.

${ }^{16}$ Ibid.

${ }^{17}$ P. Fadibo, 2007, «problématique de l'accès aux soins de santé dans le district sanitaire de Ngaoundéré (1916-2010) »

(In.) De l'adamawa à l'adamoua, Hamadou Adama (Dir.), p 128.

${ }^{18}$ Ibid.

${ }^{19}$ F. Fournet et G. Salem, 2004, « la santé dans les villes Africaines, d'idées reçues à la définition d'une urgence de santé publique » Médecine tropicale, 64, 6, p. 567.

${ }^{20}$ V. Lucas, F. Tonnellier, 1997, « les indicateurs de Santé en milieu urbain et zones rurales », aujourd'hui actualité et dossier en santé publique, 19 juin, p. 17. 
- Until 2019, the city has only 04 hospitals, 02 of which are state-owned and 02 are private, with a population of around 205,428 inhabitants.

- In urban areas, there are 01 doctors for 16,500 inhabitants, 01 health worker for 1,900 inhabitants, 01 health area every $860 \mathrm{~km} 2,01$ health area for 41,500 inhabitants, 01 health unit for 11,000 inhabitants;

- In rural areas, we have 01 doctor for 1,700 inhabitants, 01 health worker for 1,500 inhabitants, 01 health unit every 400 $\mathrm{km} 2,01$ health area for 7,200 inhabitants and 01 health unit for 4,400 inhabitants.

In view of the above, it can easily be understood that there is an inequality not only in the distribution of health infrastructure but also in the access to this infrastructure and to healthcare between the inhabitants of rural and urban areas. This inequality can be seen both in terms of infrastructure and in terms of human resources and staff. To these parameters should also be added to the quality and condition of the equipment, as well as the quality of care provided in these health facilities. Social inequalities in health in Africa do not only exist in the urban / rural dichotomy, but are also visible within the city. Indeed, it should be noted that before 1916 the health map was not yet subdivided into districts because, it was in 1955 when the districts were created, that the health map of Ngaoundéré was organized because this area depended on the Northern Province based in Garoua.

\section{BIBLIOGRAPHY}

- E. Mohammadou, 1978, les royaumes foulbés du plateau de L'Adamaoua au XIXè siècle. Tibati, Tignère, Banyo, Ngaoundéré.

- H. Paret, 1984, La planification de la santé en Afrique, paris, L’Harmattan.

- F. Sillonville, 1979, Manuel Pratique pour infirmier et éduction africain, guide de l'éducation pour la santé, Dakar, (Se).

- G. Bellongle et G. Fourier, 1975, Santé et développement en milieu rural africain : Réflexion sur l'expérience nigérienne, Paris, Ouvrière.

- G.L .Monekosso, 1998, Gestion sanitaire au niveau du district ; directive et mise en œuvre : de la médiocrité à l'excellence des prestations sanitaires, édition révisé.

- D. Kondji Kondji, 2005, politique et système de santé- Evolution historique au Cameroun: de la conceptualisation, Yaoundé- MTC- health.

- Hamadou Adama, (ed.), 2016, De l'Adamawa à l'Adamaoua, Paris, Harmattan.

- F. Fournet et G. Salem, 2004, « la santé dans les villes Africaines, d'idées reçues à la définition d'une urgence de santé publique » Médecine tropicale.

- P. Fadibo, «problématique d'accès aux soins de santé dans le district de santé de Ngaoundéré (1916-2010) », in Hamadou Adama, 2016, De l'Adamawa à l'Adamaoua Histoire, enjeux et perspectives pour le Nord-Cameroun, Etudes Africaines, Ed. L'Harmattan.

- F. Fournet et G. Salem, 2004, « la santé dans les villes Africaines, d'idées reçues à la définition d'une urgence de santé publique » Médecine tropicale, 64, 6, p. 567

- V. Lucas, F. Tonnellier, 1997, « les indicateurs de Santé en milieu urbain et zones rurales », aujourd'hui actualité et dossier en santé publique numéro : 19 juin, p. 17. 